\title{
Groundwater-surface water interactions in an ephemeral savanna catchment, Kruger National Park
}

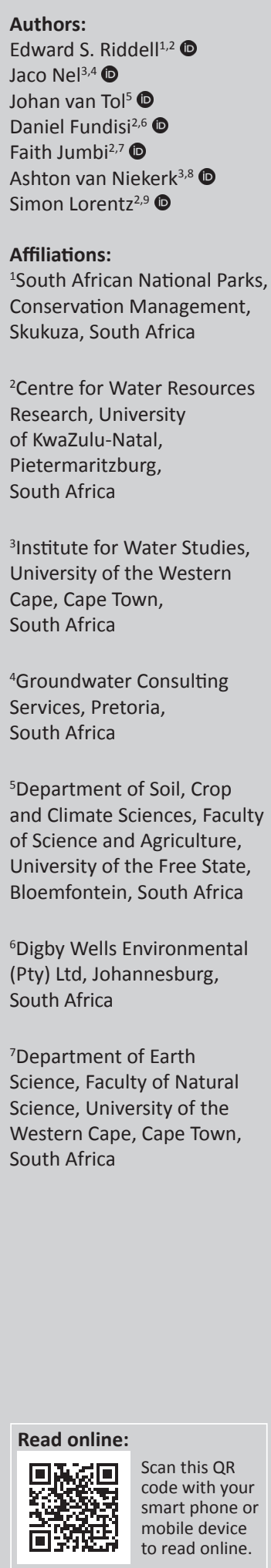

The semi-arid conditions in savanna landscapes ensure that ephemeral drainage dominates the hydrological network in these dryland systems. Quantification of their hydrological processes is important to inform ecosystem understanding and future conservation efforts under a changing climate, and to provide guidance for restoration. By combining in situ hydrometric observations, hydrochemistry, remote sensing and a soil water balance model, we characterise the groundwater-surface water interactions in ephemeral low-order catchments of the granitoid regions of the southern Kruger National Park (KNP). Streams at the lowest orders are augmented by lateral interflows from the catena, although the secondand third-order stream reaches are conduits for groundwater recharge to the fractured rock aquifer; the soils of the crests and foot-slopes also show preferential flow, and are truly recharge soils, whilst the duplex soils of the midslopes clearly show their responsive nature to a low soil moisture deficit in the shallow horizons. Actual evaporation (aET) differed between catena elements with surprisingly little variation at third-order hillslopes, with the greatest overall aET at the first order. Meanwhile, soil water balances demonstrated a significant variation in storage of the riparian zones as a result of interflow from upslope and aET losses. Furthermore, data support broader-scale observations that groundwater recharge through the vadose zone to the fractured rock aquifer is dependent upon threshold antecedent precipitation conditions. Moderate precipitation events ( $5 \mathrm{~mm} /$ day $-35 \mathrm{~mm} /$ day) over a $2-3$ week period initiate groundwater responses with a 2-3 month lag, whilst intense precipitation events (>100 mm/day) are expressed within 2-3 weeks.

Conservation implications: Understanding the lateral connectivity of terrestrial ecosystems to the ephemeral drainage network expressed via hydrological processes in these savanna landscapes is important to infer potential impacts of climate variability on the continued conservation of these ecosystems, both within and external to protected areas.

Keywords: Flow processes; Groundwater recharge; Actual evapotranspiration; Ephemeral; Granitic catchments; Savannas.

\section{Introduction}

Savanna ecosystems are characterised by open, mixed, woodland grassland, whose biomass dynamics are influenced by rainfall regime, soil characteristics, herbivory and fire, where $\sim 650 \mathrm{~mm}$ precipitation per annum limits their distribution from closed woody ecosystems (Sankaran et al. 2005). In savannas, eco-hydrological processes have been explored in terms of tree-grass interactions that inform the spatial heterogeneity in the savanna landscape. Trees and grasses are known to respond differently to rainfall and soil texture, where deep sandy soils promote tree growth, whilst shallow soil moisture on clays promotes grass growth (Staver, Botha \& Hedin 2017). Staver (2018) went on to note that the Walter Hypothesis (Walter 1971) for niche separation accounting for tree-grass coexistence, including water availability in the soil column, does not always hold true. Typically, the coupling of hydrogeological and ecological

${ }^{8}$ Department of Human Settlements, Water and Sanitation, University of Western Cape, Cape Town, South Africa

${ }^{9}$ SRK Consulting, Pietermaritzburg, South Africa

Corresponding author: Edward S. Riddell, edriddell@gmail.com

Dates: Received: 05 Sept. 2019 | Accepted: 22 Apr. 2020 | Published: 29 Oct. 2020

How to cite this article: Riddell, E.S., Nel, J., Van Tol, J., Fundisi, D., Jumbi, F., Van Niekerk, A. et al., 2020, 'Groundwater-surface water interactions in an ephemeral savanna catchment, Kruger National Park', Koedoe 62(2), a1583. https://doi.org/10.4102/koedoe.v62i2.1583 Copyright: @ 2020. The Authors. Licensee: AOSIS. This work is licensed under the Creative Commons Attribution License.

Note: Special Issue: Connections between abiotic and biotic components of a granite catena ecosystem in Kruger National Park, sub-edited by Beanelri Janecke and Johan van Tol. 
processes in these systems is controlled by limited water availability in such semiarid conditions, and this in turn leads to an optimal state of soil water stress allowing for the coexistence of trees and grasses (Rodríguez-Iturbe et al. 1999). This is certainly true of South Africa's Lowveld savannas and those of the Kruger National Park (KNP) in particular. Here, landscape patterns are closely organised around a drainage network hierarchy, resulting in clearly defined hillslope catenas (Venter, Scholes \& Eckhardt 2003). This in turn allows for a structured and diverse biotic assemblage evolving over time from a stable geological template and topographical water distribution. Venter's (1990) land classification described the landscape organisation ranging from distinct elements on the hillslope catena to broad-scale zones influenced by geology and climate. Jacobs et al. (2007) showed that moisture regimes are highly variable in the KNP, with the savannas being a temporal control on nutrient cycling and export towards the riparian zone downslope. The aquatic-terrestrial linkages along the approximately $30000 \mathrm{~km}$ of seasonal and ephemeral streams in the KNP have long been recognised as important in the landscape, although often overlooked in favour of the $600 \mathrm{~km}$ of perennial river reach (O'Keeffe \& Rogers 2003).

The management of surface and groundwater resources, especially in the highly variable water regimes characteristic of these semiarid areas, requires the description and quantification of their hydrological processes (Lorentz et al. 2008; Uhlenbrook, Wenninger \& Lorentz 2005). This has a significant bearing for conservation management under long-term climate variability and its impact on ecosystem fluxes. Identifying hydrological connectivity is thus crucial to account for configuration of moisture residence time, the distribution of saturation patterns, quantification of flow mechanisms and thresholds of flow generation as functions that contribute to drainage in these catchments and the ecosystem services they provide (Haga et al. 2005; Lorentz et al. 2008; Wenninger et al. 2008).

The KNP Supersites (Smit et al. 2013) were assigned as longterm living laboratories to stimulate cohesive science, focussing on both biotic and abiotic processes in the savanna landscape. A conceptual framework for the classification of the savanna landscape was premised on the spatiotemporal distribution of water as a key driver for geomorphological and ecological processes with feedback effects on hydrological processes. Cullum et al. (2016) described this organisation as archetypes of bio-geomorphic interaction. This article builds on these foundations by determining the hydrological connectivity of surface water, groundwater and vadose zone interactions within the ephemeral first- to third-order streams in the Southern Granite Supersite. In determining the spatiotemporal interconnectedness between hydrological process domains, one should then understand the hydrological fluxes that contribute to the savanna system dynamics. Hydrometric approaches provide for an integrated understanding of hydrological connectivity in these catchments; however, there is a particular focus on processes at the third-order system, whose hydrometric observations are used to confirm or reject the conceptual understanding of these systems from a hydrological perspective.

\section{Research method and design}

The Southern Granite Supersite (Figure 1) is situated in the Renosterkoppies land type (Venter 1990) and lies at the watershed situated between the catchments of the perennial

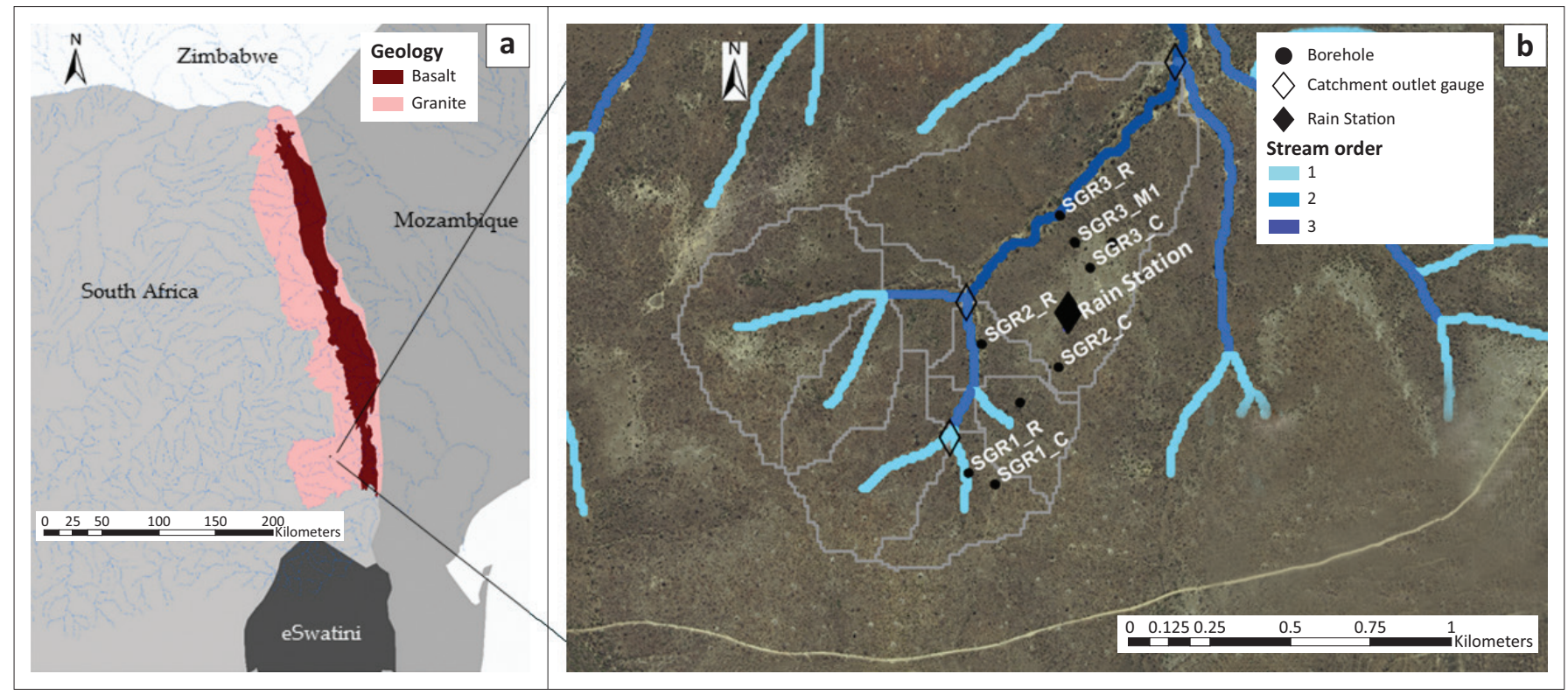

KNP, Kruger National Park; SGR, Southern Granite Supersite; 1, streamflow 1; 2, streamflow 2; 3, streamflow 3; R, riparian zone; C, crest; $M$, midslope

SGR1_R, Southern Granite Supersite streamflow 1 riparian zone; SGR1_C, Southern Granite Supersite streamflow 1 crest; SGR2_R, Southern Granite Supersite streamflow 2 riparian zone; SGR2_C, Southern Granite Supersite streamflow 2 crest, SGR3_R, Southern Granite Supersite streamflow 3 riparian zone; SGR3_M1, Southern Granite Supersite streamflow 3 midslope, SGR3_C, Southern Granite Supersite streamflow 3 crest.

FIGURE 1: (a) Location of the KNP within South Africa's borders indicating its two main geology formations present and (b) location of Southern Granite Supersite within KNP, including the orientation of the hydrometric network along three stream orders (first, second and third with their associated hillslope catenas and riparian zones). 
Sabie and the Crocodile rivers. It also falls within the Nelspruit Granite-Migmatite Complex, which has distinctive textural varieties such as gneiss and porphyritic granite, of which the flat batholith regions have much higher quartz content than the outcropping tors and inselbergs (Dippenaar \& Van Rooy 2014). This supersite sits within the N'waswitshaka sub-catchment of the Sabie River (South African quaternary drainage region X31M and InkomatiUsuthu Water Management Area). The Renosterkoppies land-type hillslopes were described by Venter (1990) as having convex well-drained interfluvial areas on the hillslope crests with a general slope of $10 \%$ and convex to concave poorly drained midslopes $(1 \%-13 \%)$; meanwhile, the footslopes $(<9 \%)$ were poorly to moderately drained, with the valley bottoms themselves being concave and part of the drainage network. Du Toit (1998) described the geohydrology of the Nelspruit Suite with expected water strikes between $10 \mathrm{~m}$ and $50 \mathrm{~m}$, with low borehole yields (typically $<1 \mathrm{~L} / \mathrm{s}$, and rarely $>5 \mathrm{~L} / \mathrm{s}$ ). Acacia nilotica is common on the lower slopes and Euclea divinorium has an association with the duplex sodic soils of the midslopes, whilst Terminalia sericea predominate the crests. More detailed descriptions of the vegetation along the catena are provided in Janecke (2020), Theron et al. (2020) and Van Aardt et al. (2020).

Note that the terminology SGR1, SGR2 and SGR3 refers to first, second, third orders, respectively (Figure 1). Meanwhile, $\mathrm{C}, \mathrm{M}$ and $\mathrm{R}$ refer to crest, midslope and riparian zones, respectively. The presentation of groundwater, stream network or catena hydrological data will be in the context of these units explicitly, and the discussion will integrate these observations.

All hydrometric and hydrochemical data presented emanate from an intensive monitoring campaign during the hydrological year, October 2012-September 2013, during which a total precipitation depth of $774 \mathrm{~mm}$ was received.

An in situ Davis ${ }^{\mathrm{TM}}$ Vantage Pro2 weather station was used to collect meteorological data on a 15-min time step using the following International System of Units (SI): tippingbucket precipitation gauge (calibrated to $0.1 \mathrm{~mm}$ ); temperature $\left({ }^{\circ} \mathrm{C}\right)$ and relative humidity (\%) using a Davis Vantage Pro2 temperature sensor (PN Junction Silicon Diode) and relative humidity sensor (Film capacitor element); wind speed $(\mathrm{m} / \mathrm{s})$; and solar radiation $\left(\mathrm{W} / \mathrm{m}^{2}\right)$. The 7-day Antecedent Precipitation Index $\left(\mathrm{API}^{7}\right)$ of Kohler and Linsley (1951) was used to differentiate rainfall sequences, as follows:

$I=b_{1} P_{1}+b_{2} P_{2}+b_{3} P_{3} \ldots . .+b_{4} P_{4}$

[Eqn. 1]

where $P_{i}$ precipitation is depth $i$ days prior to the event under consideration, and $b_{i}$ is a constant applied as a function of time, in this case seven days.

Electrical resistivity tomography (ERT) was conducted during July 2011 along the hillslopes from stream thalweg to crest in each of SGR1, SGR2 and SGR3. Georeferenced transects were predetermined using satellite imagery via the
Google Earth ${ }^{\odot}$ engine. The data informed the preliminary conceptual model for the catchment and resultantly were used to identify suitable locations to drill a piezometric borehole network. In ERT, electrical potential in the nearsurface is reliant on the electrical resistance of earthen materials, expressed in ohm metres $(\Omega . m)$. Because of the pore size, water content and salinity distribution, this varies according to subsurface strata (Loke 1999). A SAS1000 $\mathrm{ABEM}^{\mathrm{TM}}$ Terrameter and Switching unit was used for these surveys. The locations of each probe were recorded with a Trimble $^{\mathrm{TM}}$ ProXRS Asset Surveyor differential Global Positioning System (GPS). Using TrigNET (http://www. trignet.co.za/) beacon data, probe elevations were differentially corrected against the closest available station at Nelspruit. Long and short Schlumberger acquisition arrays were selected for maximum horizontal and vertical resistivity resolution near the surface, required for the vadose zone aspects, as well as good penetration depth. Resistivity pseudo-sections were generated using the algorithm RES2DINV (Geotomo Software). Using the criterion that noticeable geological features such as faults or lineaments are observable from discontinuities in modelled resistivity pseudo-sections, these ERT data were used to delineate weathered material from potential fractured rock flow conduits in the subsurface.

The South African Department of Water Affairs (now known as the Department of Human Settlements, Water and Sanitation) used air percussion borehole drilling along the geophysics traverses between June and August 2012. Boreholes were drilled into both the shallow weathered material and the consolidated hard rock, each of which was characterised by Constant Discharge Test, Recovery Test and Slug Test to determine aquifer hydraulic properties such as transmissivity $(T)$ and hydraulic conductivity $(K)$. These hydraulic properties were calculated using Theis (1935), Cooper and Jacob (1946), Hantush (1962) and Bouwer and Rice (1976) equations, with a corrective factor applied for confined aquifer conditions. A Solinst ${ }^{\mathrm{TM}}$ dip meter was used to collect monthly groundwater-level data, with more frequent readings following large rainfall events (typically bi-weekly). Specific depth hydrochemical sampling took place at similar frequency with samples collected at $10 \mathrm{~m}$ increments down the boreholes. In situ hydrochemical parameters were measured using a YSI ${ }^{\mathrm{TM}}$ (Yellow Spring Incorporated) sonde multiparameter monitoring device. Plastic bottles with $25 \mathrm{~mL}$ samples were kept in cool storage before transport to the laboratory.

A Los Gatos Research (LGR) DT-100 Liquid Water Laser Analyser was used for stable isotope analysis. Precision was achieved by six repeated samples using standards for Indian

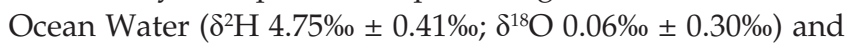
Spring Water (Avian Bottled Water $\delta^{2} \mathrm{H}-61.43 \% \pm 0.56 \% ; \delta^{18} \mathrm{O}$ $-4.05 \%$ $\pm 0.29 \%$ ). International Atomic Energy Agency (IAEA) standards LGR2, VSMOW2 and IA-RO53 were also used to derive standard deviations of $\delta^{2} \mathrm{H}(<2 \%)$ and $\delta^{18} \mathrm{O}(<0.3 \%)$. 
Stream outlets were each fitted with a Solinist ${ }^{\mathrm{TM}}$ Levelogger Junior $^{\mathrm{TM}}$ within perforated polyvinyl chloride (PVC) piezometers, inside a $110 \mathrm{~mm}$ perforated metal casing. These were logged at a 5-min time step for acquisition of high temporal resolution stage data with barometric compensation using a Solinst ${ }^{\mathrm{TM}}$ Barologger. Stream bed surface was used as the datum for stage height, whilst riverbed longitudinal and cross-sectional surveys were conducted using a DT5A SOKKIA surveyor's theodolite. The Concalcs HydroToolBox (Renshaw 2010) was used to determine wetted perimeter cross-sections and the slope-area method (Herschy 1995) to determine discharge rating curves with Manning's channel roughness coefficients (Cowan 1956). A Microsoft Access database was used to compute discharges using polynomial rating equations.

The Surface Energy Balance Algorithm for Land model, SEBAL (Bastiaanssen et al. 1998), was used to determine actual evapotranspiration (aET), and data were provided by the WATPLAN project (Van Eekelen et al. 2015). This uses the residual of the surface energy equation acquired through remotely sensed images of visible and nearinfrared spectroscopy to estimate actual evapotranspiration (Courault, Seguin \& Olioso 2005). Daily aET is calculated via linear interpolation of the reference evapotranspiration $\left(\mathrm{ET}^{0}\right)$ fraction over the period between pixels of two consecutive images, then multiplying this by the cumulative $24 \mathrm{~h} \mathrm{ET}^{0}$ for that day. Visible and near-infrared data from the images ( $22 \mathrm{~m}$ resolution) and Landsat-7 data $(30 \mathrm{~m})$ were used to produce seven-day aET rasters. A cumulative daily aET time series was developed by fitting the Penman-Montieth reference evaporation trend, derived from the meteorological station, to the exported raster data, disaggregated per catena unit.

Irrometer $^{\mathrm{TM}}$ WaterMark soil moisture sensors measuring di-electrical resistance of porous medium in kilo-ohms $(\mathrm{k} \Omega)$ were used to determine the characteristic subsurface unsaturated soil-water dynamics within catena soils adjacent to the boreholes and were installed within each of the first three soil horizons at these locations. Tension Disc Infiltrometers were used to determine the soil unsaturated hydraulic conductivity $\left(K_{\text {unsat }}\right)$ at four matric potentials according to the protocol of Ankeny et al. (1991) and permeameters were used for the saturated hydraulic conductivity, $K_{\text {sat }}$ (Abit et al. 2002)

HYDRUS-1D (Šimůnek et al. 2013) was used to model the hillslope water balance using atmospheric inputs and soil hydraulic parameters, and thereby determine hydrological fluxes and water budgets for each element of the hillslope catena. HYDRUS-1D numerically solves the Richard's equation (1931) for variably saturated water flow. The modelling period was from 03 October 2012 to 30 April 2013, totalling 5040 hourly time steps. The domain set-up for each catena element was according to horizon depths and soil textural classes. An atmospheric boundary condition was applied at the surface, including surface runoff, with a free drainage boundary at the base of the model domain. Initial conditions were set in matric potential $(\varphi)$, according to observed values from watermark sensors.

\section{Ethical considerations}

This article followed all ethical standards for research without direct contact with human or animal subjects.

\section{Results \\ Subsurface resistivity distribution and static conditions}

At SGR1, the unsaturated zone is approximately $8 \mathrm{~m}$ deep, with variable moisture contents expressed because of the presence of low resistivity regions ( $3 \Omega . \mathrm{m}-75 \Omega . \mathrm{m}$ ) (Figure 2, Table 1). Thus, the groundwater level was expected to be at a depth of approximately $8 \mathrm{~m}-10 \mathrm{~m}$ across the profile. Deep weathering is noted in the riparian zone, which then decreases in depth towards the crest because of the presence of high resistivity material (1875 $\Omega . \mathrm{m}-5484 \Omega . \mathrm{m})$ at shallow depths. The alignment of resistivity $219 \Omega . m-641 \Omega . m$ at $20 \mathrm{~m}-25 \mathrm{~m}$ depth across the hillslope indicates an interface zone between the weathered material and the fractured hard rock.

At SGR2, the riparian zone shows deep weathering, which decreases upslope because of the higher resistivity values (1875 $\Omega . m-5484 \Omega . m)$ at a shallow depth towards the crest. However, shallower weathering was revealed during the drilling at the riparian boreholes as compared to the crests with depths of approximately $29 \mathrm{~m}$ and $43 \mathrm{~m}$, respectively.

At SGR3, an unsaturated weathered zone exists at a depth of $8 \mathrm{~m}-12 \mathrm{~m}$. At the riparian zone, high resistivity material (1875 $\Omega . \mathrm{m}-5484 \Omega . \mathrm{m}$ ) occurs at $25 \mathrm{~m}, 26 \mathrm{~m}$ at the midslope and approximately $35 \mathrm{~m}$ at the crest. A significant sodic site (duplex fine-textured soils) is present at the midslope, which explained the low resistivity values ( $3 \Omega . m-75 \Omega . m$ ) from there towards the crest. Drilling exposed the weathering profile to be at $25 \mathrm{~m}, 26 \mathrm{~m}$ and $38 \mathrm{~m}$ at the riparian zone, midslope and crests, respectively. The riparian boreholes had a very low $T$ of $4.80 \mathrm{E}-03 \mathrm{~m}^{2} /$ day; therefore, low permeability conditions exist in both shallow and deep groundwater systems. The midslope and crest positions had $T$ values of $3.3 \mathrm{~m}^{2} /$ day $-4.7 \mathrm{~m}^{2} /$ day and $9 \mathrm{~m}^{2} /$ day, respectively.

\section{Groundwater processes}

Groundwater responses along the three transects are shown in relation to the daily rainfall totals where three key rainfall sequences were identified through the $\mathrm{API}^{7}$ (Figure 3). This figure should be interpreted together with the data presented in Table 2, summarising the change in groundwater head during these periods. 


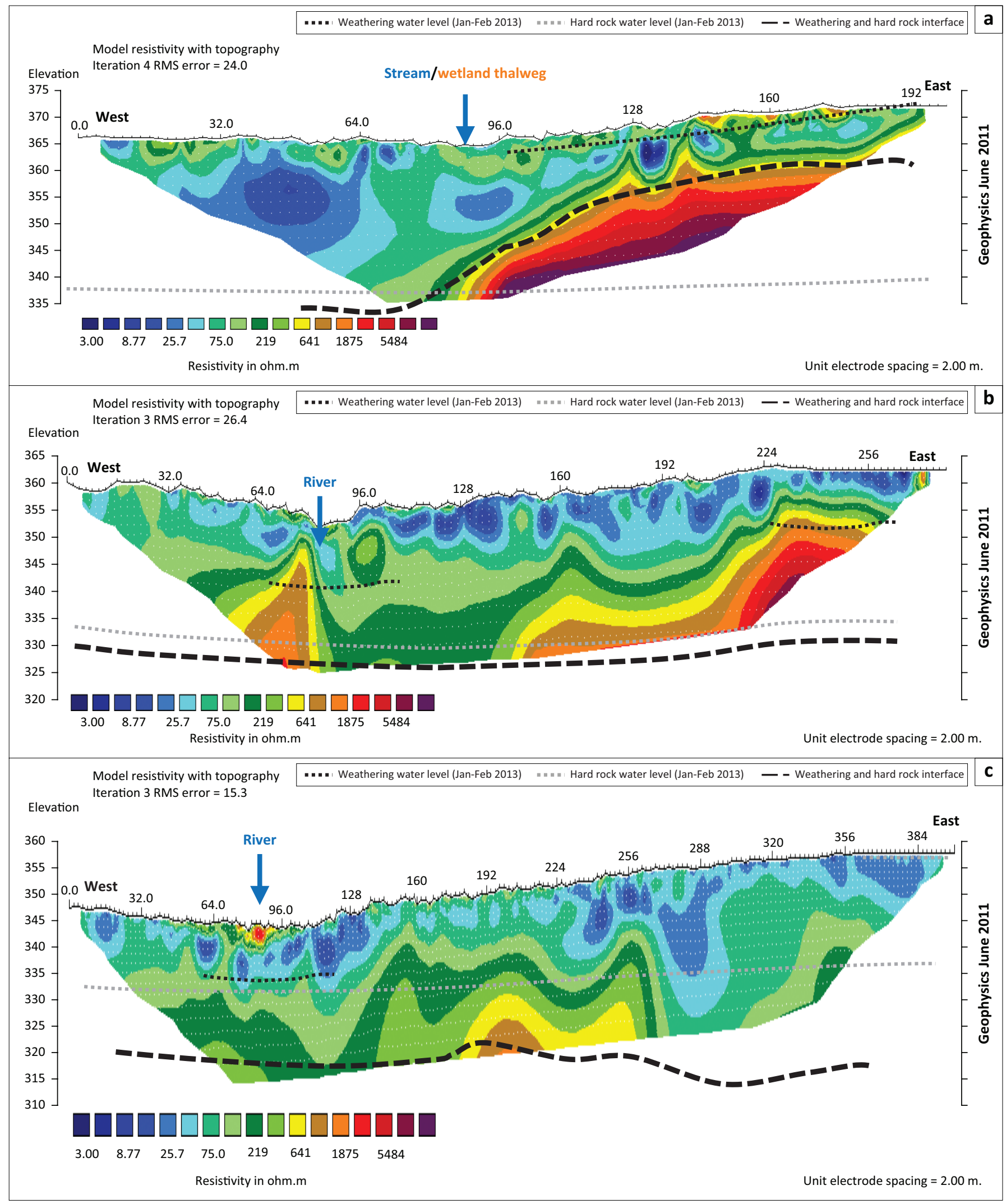

FIGURE 2: Electrical resistivity tomography distribution for the three hillslope stream orders at the Southern Granite Supersite (where a, b, and c represent Southern Granite Supersite 1, Southern Granite Supersite 2 and Southern Granite Supersite 3, respectively). 


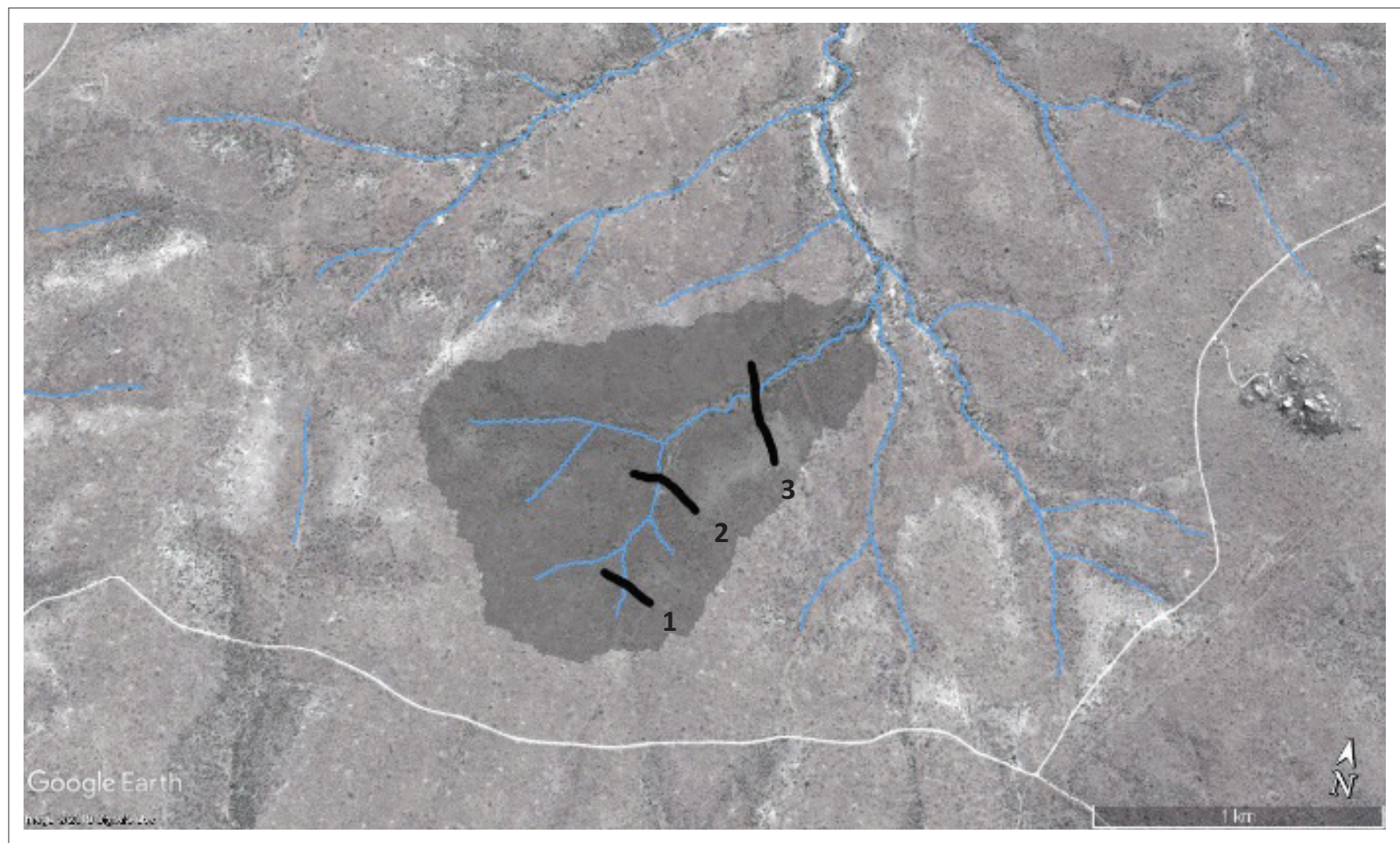

FIGURE 2 (Continues ...): Electrical resistivity tomography distribution for the three hillslope stream orders at the Southern Granite Supersite (where 1,2 and 3 represent Southern Granite Supersite 1, Southern Granite Supersite 2 and Southern Granite Supersite 3, respectively).

TABLE 1: Borehole hydraulic parameters determined following drilling during 2012. (SGR1, SGR2, SGR3 = first, second and third Southern Granite Supersite orders, respectively. Meanwhile $C, M$ and $R=$ crest, midslope and riparian, respectively).

\begin{tabular}{|c|c|c|c|c|c|c|c|}
\hline Borehole ID & Borehole depth (m) & Temp $\left({ }^{\circ} \mathrm{C}\right)$ & Specific conductance $(\mathrm{mS} / \mathrm{m})$ & $\mathrm{pH}$ & Static water level (m) & Blowout yield (L/s) & Transmissivity $\left(\mathrm{m}^{2} /\right.$ day $)$ \\
\hline SGR3_R_43 & 43 & 24.6 & 400 & 6.9 & 17.71 & 0.011 & $4.80 \mathrm{E}-03$ \\
\hline SGR3_R_20 & 20 & 24.4 & 384 & 6.9 & 17.97 & None & $1.80 \mathrm{E}-04$ \\
\hline SGR3_M_49 & 49 & 25.2 & 319 & 7.1 & 22.67 & 0.16 & 3.3 \\
\hline SGR3_M_26 & 26 & 25.0 & 314 & 6.7 & 22.85 & 0.29 & 2.5 \\
\hline SGR3_M_23 & 23 & 24.9 & 352 & 6.9 & 22.89 & None & None \\
\hline SGR3_C_55 & 55 & 26.0 & 220 & 7.2 & 26.83 & 0.33 & 9 \\
\hline SGR3_C_34 & 34 & 26.0 & 406 & 7.0 & 26.80 & None & $1.20 \mathrm{E}-04$ \\
\hline SGR2_C_40 & 40 & 25.1 & 487 & 6.7 & 34.92 & None & $1.90 \mathrm{E}-05$ \\
\hline SGR2_C_55 & 55 & 25.2 & 302 & 7.2 & 34.69 & None & $5.90 \mathrm{E}-08$ \\
\hline SGR2_R_28 & 28 & 25.2 & 487 & 6.3 & 24.21 & None & 0.02 \\
\hline SGR2_R_49 & 49 & 25.3 & 301 & 7.2 & 24.18 & None & $1.40 \mathrm{E}-03$ \\
\hline SGR1_R_61 & 61 & 25.5 & 208 & 7.0 & 33.48 & 0.07 & 0.5 \\
\hline SGR1_R_22 & 22 & None & None & None & Dry & None & None \\
\hline SGR1_C_103 & 103 & 25.9 & 233 & 7.1 & 38.82 & 1.25 & 11.2 \\
\hline
\end{tabular}

At SGR1, the $17 \mathrm{~m}$ crest borehole (SGR1_C) had more than $20 \mathrm{~m}$ difference in groundwater head following heavy rains. Meanwhile, the $103 \mathrm{~m}$ borehole, drilled into the hard rock, had a lag of two months in response to rainfall sequence 1 (see Table 2) of $5 \mathrm{~mm} /$ day- $31 \mathrm{~mm} /$ day during two weeks in September 2012, with an increase in groundwater head over time $(\Delta h / \Delta t)$ of $0.08 \mathrm{~m}$. This increased by $0.09 \mathrm{~m}$ during the moderate second rainfall sequence of $5 \mathrm{~mm} /$ day $-35 \mathrm{~mm} /$ day over three weeks. $\Delta h / \Delta t$ increased by $0.32 \mathrm{~m}$ during the December 2012-August 2013 period, whilst the $\Delta h / \Delta t$ increased significantly following the intense rainfall of December 2012-February 2013. The riparian $61 \mathrm{~m}$ borehole
(SGR1_R) also responds to the major rainfall sequences, similar to the $103 \mathrm{~m}$ crest borehole, the only difference being that the borehole in the riparian zone has a slightly higher hydraulic head. A subtle positive gradient occurs from the riparian zone towards the crest.

At SGR2_C, both boreholes track a similar water level depth. During the second rainfall sequence, the $55 \mathrm{~m}$ borehole $\Delta h$ raises by $0.20 \mathrm{~m}$ over two months. The modest sequence of rainfall events $(10 \mathrm{~mm} /$ day $-35 \mathrm{~mm} /$ day over three weeks) during October 2012 triggered the $\Delta h / \Delta t$ to increase by 4.38 $\mathrm{m}$ and returned a month later to a static deep groundwater 

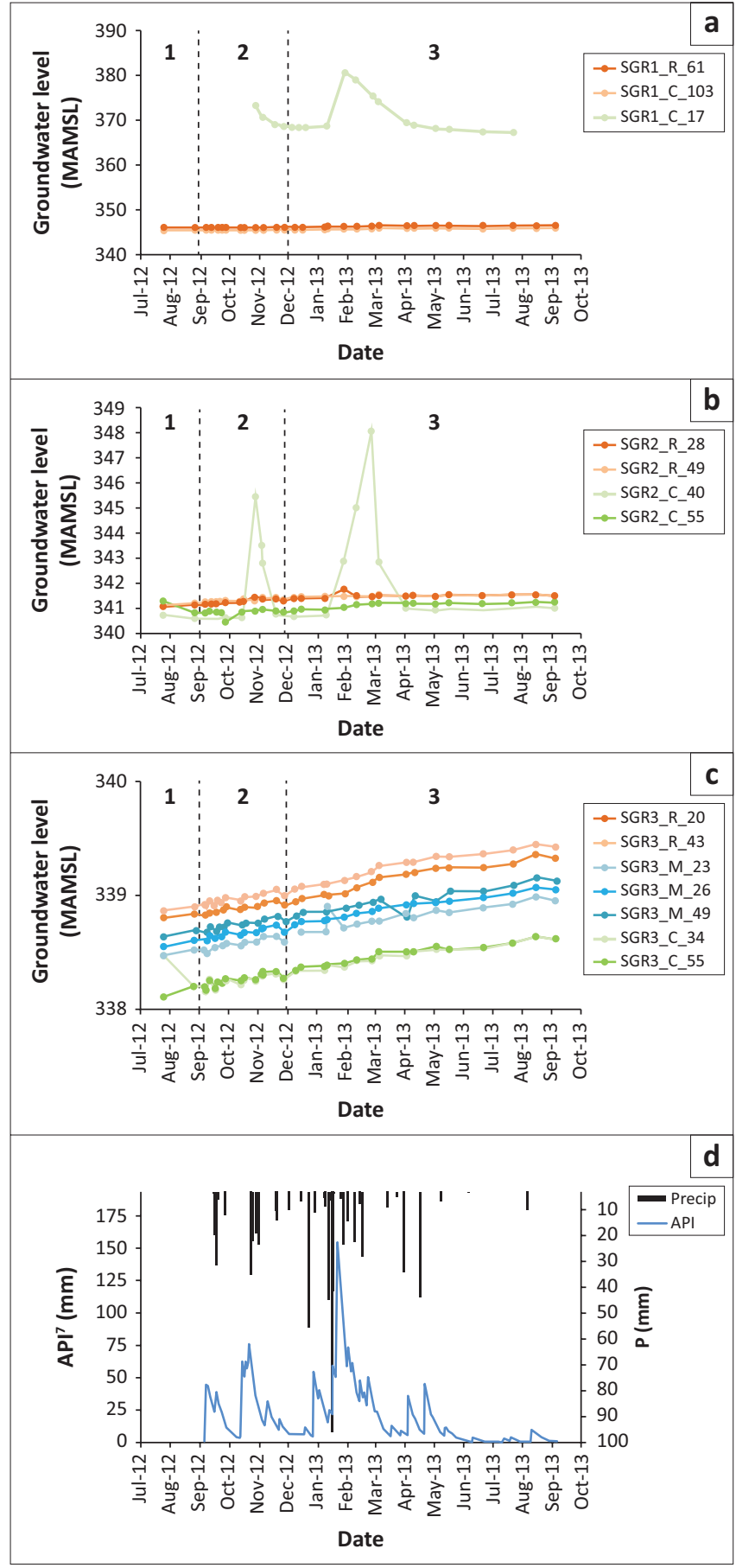

Seven-day Antecedent Precipitation Index periods (1,2 and 3) separated by vertical dashed lines and $\mathrm{Y}$-axis variations for each groundwater level series, crest, midslope, riparian, respectively.

$\mathrm{API}^{7}$, Seven-day Antecedent Precipitation Index; C, crest; M, midslope; R, riparian.

FIGURE 3: Groundwater hydrodynamics and seven-day Antecedent Precipitation Index for Kruger National Park Granite Supersite 2012-2013.

level. However, a significant rise of $7.39 \mathrm{~m}$ arose as a result of the high-intensity rainfall sequence 3 (including over 200 mm during six days in January 2013) and regressed approximately two months later to the static deep level in the hard rock (cautionary note: these abrupt changes in water level could be attributed to a borehole construction error, with conduits). At SGR2_R, groundwater in the riparian zone also showed that both boreholes track each other expressing similar water levels. Rainfall sequence 2 ( $5 \mathrm{~mm} /$ day $-35 \mathrm{~mm} /$ day) allowed
TABLE 2: Groundwater head $(m)$ changes expressed against the seven-day Antecedent Precipitation Index periods during 2012-2013.

\begin{tabular}{lccc}
\hline Borehole & \multicolumn{3}{c}{$\boldsymbol{\Delta} \boldsymbol{h} \boldsymbol{\Delta \boldsymbol { t }}$} \\
\cline { 2 - 4 } & $\mathbf{1}$ & $\mathbf{2}$ & $\mathbf{3}$ \\
\hline API7 Total (mm) & $\mathbf{8 7 . 3}$ & 167.7 & 390 \\
Date & September & October-November & After December \\
& 2012 & 2012 & 2012 \\
SGR3_R_43 & 0.12 & 0.08 & 0.39 \\
SGR3_R_20 & 0.09 & 0.05 & 0.41 \\
SGR3_M_49 & 0.12 & 0.06 & 0.31 \\
SGR3_M_26 & 0.13 & 0.06 & 0.31 \\
SGR3_M_23 & 0.11 & 0.02 & 0.28 \\
SGR3_C_55 & 0.16 & 0.07 & 0.28 \\
SGR3_C_34 & 0.06 & 0.08 & 0.29 \\
SGR2_C_55 & - & 0.2 & 0.32 \\
SGR2_C_40 & - & 0.2 & 0.38 \\
SGR2_R_49 & 0.17 & 0.12 & 0.09 \\
SGR2_R_28 & 0.16 & 0.14 & 0.11 \\
SGR1_R_61 & 0.08 & 0.05 & 0.35 \\
SGR1_R_103 & 0.08 & 0.09 & 0.32
\end{tabular}

$\mathrm{API}^{7}$, seven-day Antecedent Precipitation Index; SGR, Southern Granite Supersite; R, riparian; $\mathrm{M}$, midslope; C, crest.

a $\Delta h / \Delta t$ increase by $0.12 \mathrm{~m}$ and $0.14 \mathrm{~m}$ for the $49 \mathrm{~m}$ and $28 \mathrm{~m}$ boreholes, respectively. Meanwhile, both deep and shallow levels follow a more gradual gradient during sequence 3 . The shallow $28 \mathrm{~m}$ borehole $\Delta h / \Delta t$ increased by $0.35 \mathrm{~m}$ because of the intense rain of January 2013, with a twoweek response time. The close proximity of these boreholes to the stream network and the rapid rise and fall of groundwater head in the shallow riparian zone indicates a through-flow system. There is also a moderate hydraulic gradient away from the stream away from SGR2_R, as expressed by the lower groundwater level in the crest position at SGR2_C.

At SGR3_C, both boreholes follow similar trends. There is a relatively steep gradient during September 2012 because of equilibration of the borehole following its installation, thereby not representative of ambient groundwater conditions. During September 2012, the $\Delta h / \Delta t$ rose by $0.16 \mathrm{~m}$ and $0.06 \mathrm{~m}$ for the $55 \mathrm{~m}$ and $34 \mathrm{~m}$ boreholes, respectively, with a $\Delta h / \Delta t$ increase of $0.07 \mathrm{~m}$ and $0.08 \mathrm{~m}$ during rainfall sequence 2 . Then, the $55 \mathrm{~m}$ and $34 \mathrm{~m}$ boreholes' $\Delta h / \Delta t$ elevated again by $0.28 \mathrm{~m}$ and $0.29 \mathrm{~m}$, respectively, where an increased gradient is observed after the high-intensity January 2013 events. This continues for two months after which it follows a more gradual gradient. At the midslope, the $49 \mathrm{~m}$ borehole has a higher elevation than the $23 \mathrm{~m}$ and $26 \mathrm{~m}$ boreholes and therefore a pressure gradient exists towards the shallower boreholes. A $0.31 \mathrm{~m}, 0.28 \mathrm{~m}$ and $0.23 \mathrm{~m}$ change in $\Delta h / \Delta t$ for the $55 \mathrm{~m}, 26 \mathrm{~m}$ and $23 \mathrm{~m}$ boreholes, respectively, was observed between December 2012 and August 2013, signifying a high recharge period. At SGR3_R, the $43 \mathrm{~m}$ borehole has a groundwater-level pressure greater than the $20 \mathrm{~m}$ borehole, indicative of a hydraulic gradient away from the stream. The $\Delta h / \Delta t$ increased by $0.39 \mathrm{~m}$ and $0.41 \mathrm{~m}$ for the $43 \mathrm{~m}$ and $20 \mathrm{~m}$ boreholes, respectively, with a significant change in gradient during the third rainfall sequence. 


\section{Streamflow}

Streamflows (Figure 4) were very intermittent and directly linked to rainfall events. Runoff coefficients decreased at each increment in catchment order for low-intensity sequences with $\mathrm{API}^{7}$ 's below $50 \mathrm{~mm}$. The first-order stream (SGR1) had observable base flow, having the longest flow duration, albeit with the lowest peak flow; this would result from gains from groundwater and/or hillslope contributions. The third order (SGR3) meanwhile had the greatest peak flows but the lowest flow duration, and therefore high transmission losses and close to zero base flow contributions.

\section{Stable isotopes}

Figure 5 shows the $\mathrm{d}^{18} \mathrm{O}$ end-members for groundwater and surface water from the beginning of September 2012 until the end of January 2013. There is a clear distinction from September through December 2012, with more depleted values for groundwater (low delta values) than the surface waters. This likely results from enriched precipitation arising from convective air masses early in the rain season, whereas in the large events of January 2013, the surface waters also show a depleted signature, indicative of either mixing with pre-event groundwater

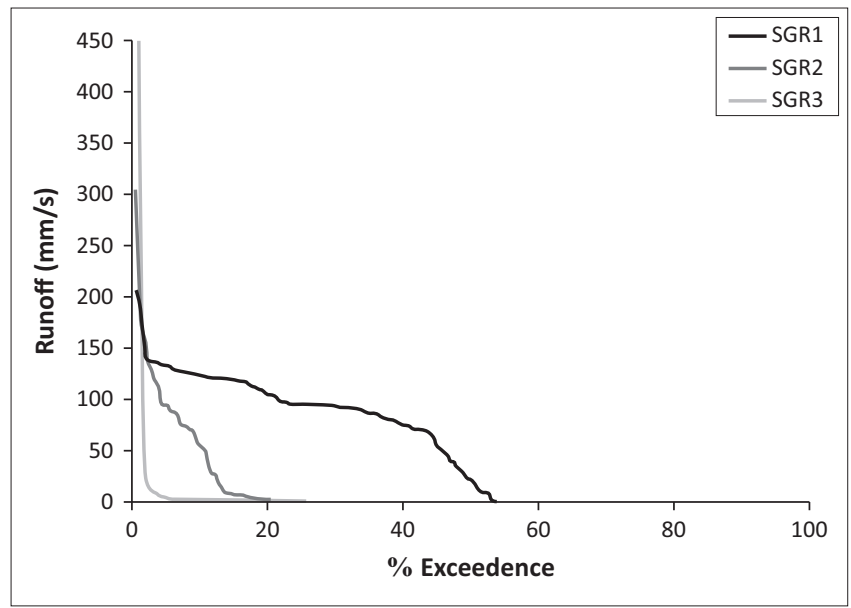

SGR, Southern Granite Supersite.

FIGURE 4: Flow duration curve for the three different order catchment outlets (SGR 1, SGR 2, SGR 3) September 2012-April 2013.

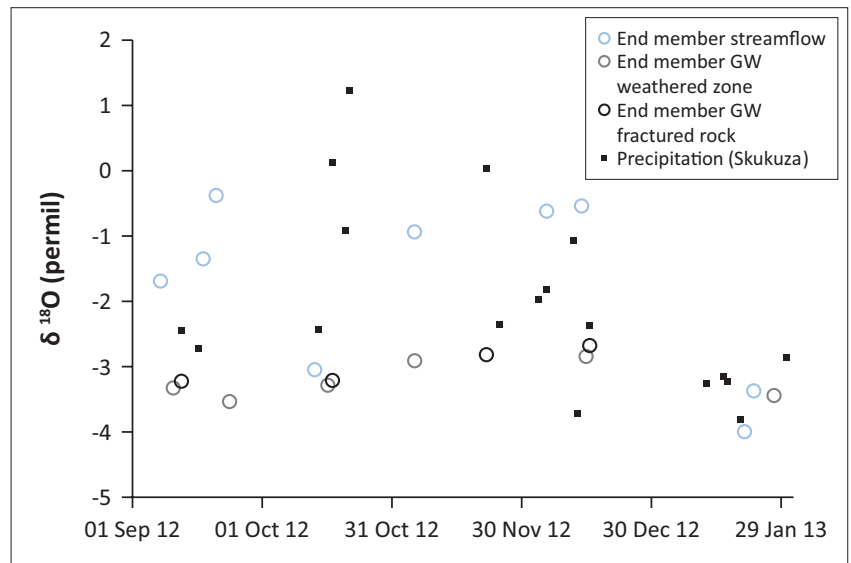

FIGURE 5: Time series of $\mathrm{d}^{18} \mathrm{O}$ isotopes in groundwater and surface water during the study period. and/or depleted rainfall arising from frontal oceanderived weather systems.

\section{Soil water}

For the sake of brevity, only the soil moisture responses for SGR3 are presented here. The reader is also referred to detailed work on the pedotransfer functions of these soils in Van Tol et al. (2020). Nevertheless, Table 3 summarises the matric potentials for all catchment orders during the monitoring period, with a distinction for the percentage of time that a soil was close to saturation $(\varphi=<1000 \mathrm{~mm})$ or in a drying phase $(\varphi=>1000 \mathrm{~mm}$ to $<10000 \mathrm{~mm})$. SG1R_C, SGR2_M and SGR3_M were the regions where soils were closest to saturation most frequently, whilst the remaining soils typically were not close to saturation during the monitoring period.

At SGR3_C, high $K_{\text {unsat }}$ (Table 4) was determined for the sandy loams at the soil surface $(26 \mathrm{~mm} / \mathrm{h}-76 \mathrm{~mm} / \mathrm{h}$ at $\varphi=5 \mathrm{~mm})$.

TABLE 3: Approximate duration of soil moisture at low and high matric potentials (September 2012-April 2013).

\begin{tabular}{|c|c|c|}
\hline Matric potential (mm) & $<1000$ & $<10000$ \\
\hline Depth (mm) & $\%$ Time & \% Time \\
\hline \multicolumn{3}{|l|}{ SGR1_C } \\
\hline 350 & 40 & 75 \\
\hline 500 & 44 & 80 \\
\hline \multicolumn{3}{|l|}{ SGR1_M } \\
\hline 125 & 2 & 65 \\
\hline 300 & 4 & 65 \\
\hline 450 & 0 & 60 \\
\hline \multicolumn{3}{|l|}{ SGR1_R } \\
\hline 100 & 20 & 76 \\
\hline 280 & 10 & 50 \\
\hline 1000 & 0 & 43 \\
\hline \multicolumn{3}{|l|}{ SGR2_C } \\
\hline 100 & 0 & 69 \\
\hline 250 & 2 & 75 \\
\hline \multicolumn{3}{|l|}{ SGR2_M } \\
\hline 100 & 50 & 70 \\
\hline 250 & 20 & 56 \\
\hline 400 & 20 & 81 \\
\hline \multicolumn{3}{|l|}{ SGR2_R } \\
\hline 100 & 3 & 53 \\
\hline 250 & 0 & 53 \\
\hline \multicolumn{3}{|l|}{ SGR3_C } \\
\hline 100 & 0 & 72 \\
\hline 250 & 4 & 80 \\
\hline \multicolumn{3}{|l|}{ SGR3_M1 } \\
\hline 100 & 20 & 32 \\
\hline 300 & 16 & 89 \\
\hline 800 & 0 & 71 \\
\hline \multicolumn{3}{|l|}{ SGR3_M2 } \\
\hline 100 & 3 & 55 \\
\hline 300 & 2 & 99 \\
\hline 400 & 18 & 65 \\
\hline \multicolumn{3}{|l|}{ SGR3_R } \\
\hline 100 & 5 & 47 \\
\hline 250 & 7 & 53 \\
\hline 400 & 7 & 68 \\
\hline
\end{tabular}

SGR, Southern Granite Supersite; C, crest; M, midslope; R, riparian. 
TABLE 4: Soil texture and hydraulic property characteristics for the third-order hillslope.

\begin{tabular}{|c|c|c|c|c|}
\hline & Horizon & Depth (mm) & Textural class & $K_{\text {sat }}(\mathrm{mm} / \mathrm{h})$ \\
\hline \multirow[t]{3}{*}{ SGR3_C } & A & 100 & $\mathrm{CL}$ & 163.3 \\
\hline & B & 270 & SL & 49.2 \\
\hline & C & 800 & $\mathrm{SCL}$ & 4.2 \\
\hline \multirow[t]{3}{*}{ SGR3_M1 } & A & 100 & $\mathrm{SCL}$ & 4.2 \\
\hline & B & 300 & $\mathrm{CL}$ & 3.8 \\
\hline & c & 800 & $\mathrm{CL} / \mathrm{L}$ & 2.9 \\
\hline \multirow[t]{4}{*}{ SGR3_R } & A & 100 & SL & 39.2 \\
\hline & B & 280 & $\mathrm{SCL}$ & 22.9 \\
\hline & C & 930 & $\mathrm{CL}$ & 10.4 \\
\hline & \multicolumn{4}{|c|}{ Surface $K_{\text {unsat }}(\mathrm{mm} / \mathrm{h})$} \\
\hline Matric potential $(\mathrm{mm})$ & 5 & 60 & 90 & 160 \\
\hline SGR3_C1 & 26.66 & 10.81 & 5.24 & 3.47 \\
\hline SGR3_C2 & 75.21 & 30.97 & 8.33 & \\
\hline SGR3_M1.1 & 20.11 & 13.36 & 8.95 & 1.93 \\
\hline SGR3_M1.2 & 7.87 & 7.40 & 2.80 & 0.14 \\
\hline SGR3_M2.1 & 8.55 & 3.40 & 1.98 & 1.73 \\
\hline SGR3_M2.2 & 13.39 & 3.68 & 2.13 & 1.74 \\
\hline SGR3_R1 & 9.18 & 4.12 & 3.70 & 2.88 \\
\hline SGR3_R2 & 26.28 & 17.45 & 5.40 & 1.73 \\
\hline
\end{tabular}

SGR, Southern Granite Supersite; CL, clay loam; SL, sandy loam; SCL, sandy clay loam.

Meanwhile at SGR3_M, low $K_{\text {unsat }}$ was determined at low matric potential $(7 \mathrm{~mm} / \mathrm{h}-20 \mathrm{~mm} / \mathrm{h}$ at $\varphi=5 \mathrm{~mm})$; this of course was similarly expressed with $K_{\text {sat }}$ being the lowest for the entire hillslope $(2 \mathrm{~mm} / \mathrm{h}-4 \mathrm{~mm} / \mathrm{h})$. Furthermore, a seep line exists between the SGR3_C and SGR3_M because of textural discontinuities between the two catena units. Riparian soils at SGR3_R show modest $K_{\text {unsat }}$ and $K_{\text {sat }}$ compared to the rest of the catena elements, in particular $K_{\text {sat }}$ decreases with depth indicative of slow recharge potential. Figure 6 shows the soil matric responses for the reported summer rainfall period. The crest shows that low matric potential dominates at $100 \mathrm{~mm}$ and $250 \mathrm{~mm}$ but with relatively rapid wetting-drying cycles for most precipitation events (unfortunately the $350 \mathrm{~mm}$ sensor was faulty and data were omitted). Water retention in the profile at low matric potential occurred $\sim 40 \%$ of the time resulting from the heavy rains (rainfall sequence 3 ). This implies that water is not retained at the crests and that lateral contributions to the lower slope occur.

The upper-midslope at SGR3_M1 typically had low matric potentials for shallow soils between $100 \mathrm{~mm}$ and $300 \mathrm{~mm}$, whilst the deep layers $(800 \mathrm{~mm}$ ) show a considerable lag, of a month or more, before they respond to significant wetting events. These deep soils only reach low matric potentials in response to the large January and March 2013 events; $90 \%$ of the time, these deep soils remain relatively dry (matric potential $>1000 \mathrm{~mm}$ ). It is notable that a shallow soil piezometer installed at this location remained dry after the significant rain event in January 2013. However, the lowermidslope, a response to the early rains (September 2012), is expressed throughout the profile to a depth of $400 \mathrm{~mm}$. The shallow soils show a rapid drying cycle compared to the lower horizons. Interestingly, the intermediate soils (depth = $300 \mathrm{~mm}$ ) retained moisture for much longer, whereas the deep and shallow soils dried out relatively quickly in comparison.

At SGR3_R, the entire profile responds up to a depth of 400 $\mathrm{mm}$ to most rainfall events with similar wetting and drying cycles. The observations confirm a well-drained but relatively dry profile as matric potential is $>1000 \mathrm{~mm}$ at least $90 \%$ of the time.

\section{Evapotranspiration}

Cumulative aET curves per catena unit, derived for the 2012-2013 hydrological year, are shown in Figure 7. Distinct water uses are apparent between the three elements of the catena at SGR1, with the greatest demand at SGR1_R (809 $\mathrm{mm}$ ), whereas the crest and midslope had $765 \mathrm{~mm}$ and 784 $\mathrm{mm}$, respectively. During the early rain season, between October and November, there was no real difference between the midslope and the crest region. Meanwhile, at SGR2, no significant variation between catena elements was revealed until mid-December. Then, the crest and riparian zones showed similar water use with $782.5 \mathrm{~mm}$ and $779 \mathrm{~mm}$, respectively, and midslope the least $(755 \mathrm{~mm})$. Overall, there was no significant differences in aET across catena elements at SGR3, with the highest water use at the crest $(767 \mathrm{~mm})$, followed by the riparian $(765 \mathrm{~mm})$ and then the midslope (762 mm).

\section{Catena water balance}

The summary of water balances emanating from the HYDRUS 1D simulations is shown in Table 5. At SGR1, an increase in storage of $48 \mathrm{~mm}$ was simulated at the crest, whereas the midslope and riparian zones were shown to be losing water. Interestingly, this was not expected as the crest has shallow soils; it can, however, be explained because of loss through modelled evapotranspiration (ET) at the midslope (470 mm) and riparian $(546 \mathrm{~mm}$ ) zones, as compared to the crest (294 $\mathrm{mm}$ ). Whilst the crest has a significant free drainage (FD), at the hillslope scale more water is being lost through ET, indicative of large extraction by the savanna vegetation when water is not limited.

The high FD at the crest was not expected here because of the existing E horizon, which according to Van Tol et al. (2015) should indicate perched water table conditions and thus restricted flow in some areas of the lithocutanic B. This should result in more lateral flow and less FD. Most soils in the model domain only respond to high-intensity events of approximately $>100 \mathrm{~mm} /$ day. This implies that seasons with low-to-medium intensity events will result in low or insignificant amounts of FD, and thereby low potential recharge to groundwater, especially in the lower elements of this hillslope.

At SGR2, the crest showed the most significant storage change $(45 \mathrm{~mm})$ followed by the midslope, whereas the riparian zone will lose water through ET and FD. Furthermore, the riparian zone of the second order is the only modelled 


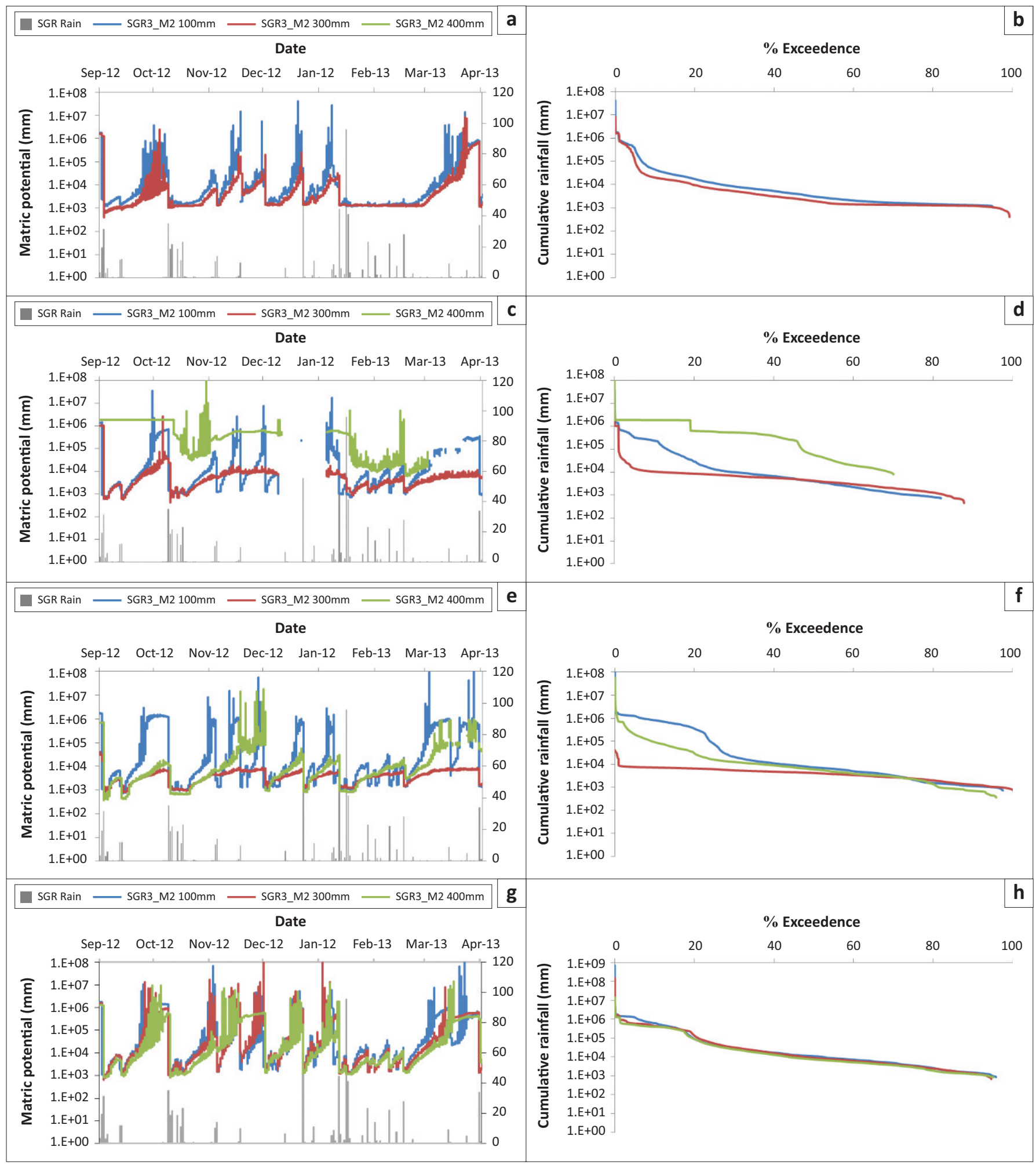

SGR, Southern Granite Supersite.

FIGURE 6: Soil matric potential responses and \% exceedence curves ${ }^{+}$at the third-order catena (September 2012-April 2013) ('note erroneous logger data excluded).

catena element that yielded surface runoff (R). It might be recalled that shallow interflow is expected here because of flow restriction of the B horizon in these duplex soils. Runoff is therefore induced from infiltration (saturation) excess. Meanwhile, ET at the second-order hillslope was the greatest on the midslope, with evaporation from the soil surface being the dominant mechanism rather than through transpiration.
However, crest and riparian zones relinquish most water through transpiration.

SGR3 catena shows the greatest storage change at the riparian zone and the crest, whilst the midslope has negative storage induced through ET losses as a result of direct soil evaporation. It also has the greatest storage (combined) 


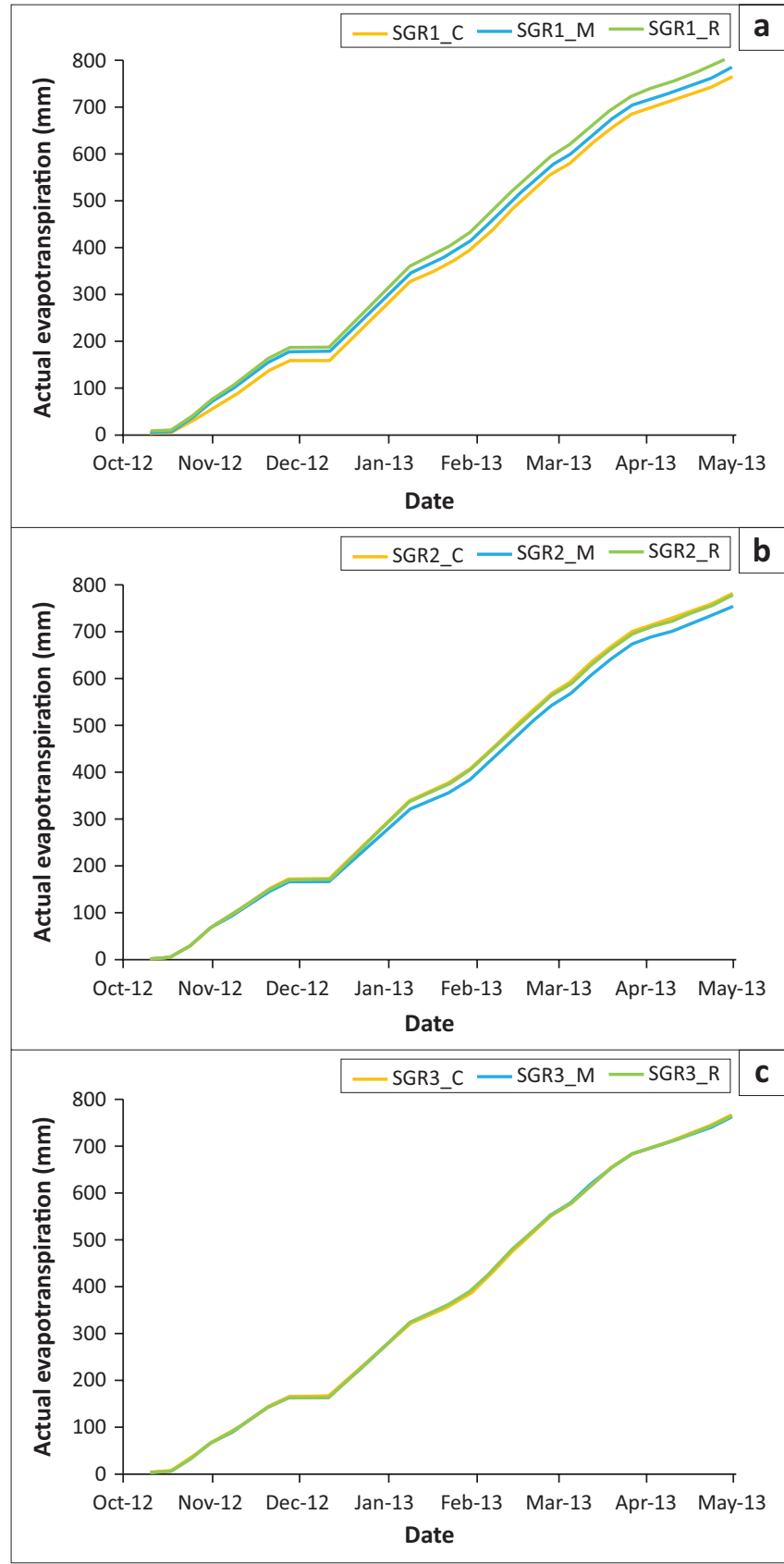

SGR, Southern Granite Supersite.

FIGURE 7: Actual cumulative evaporation derived from the Surface Energy Balance Algorithm for Land (SEBAL) model per catena unit (crest, midslope, riparian) in the Southern Granite Supersite streamflows (a) 1, (b) 2, and (c) 3.

overall compared to the lower order hillslopes. Transpiration was the dominant mechanism, at the crest and the riparian zones, because of the increased density of woody and herbaceous plants. Free drainage is greatest at the riparian zone.

\section{Discussion}

\section{The conceptual model of ephemeral hydrological processes of the Southern Granite Supersite}

At SGR1, the large difference in groundwater head between the shallow and deeper boreholes at the crest implies the presence of a perched water table above an aquitard in the shallow weathered zone. This is supported by the presence of a low resistivity material between the high resistance (deeper hard rock) and shallow (unconsolidated) materials near the hillslope surface. Meanwhile, water level trends are indicative of a direct piston recharge mechanism following a sequence of intense rainfall events causing water levels to rise. Although a perched groundwater level was not observed at SGR2, the rapid rise and fall of groundwater head in the shallow crest boreholes infer a direct piston recharge mechanism, whilst in the riparian zone, a rapid response and recession implies a direct preferential recharge mechanism providing a slight hydraulic gradient away from the stream itself, through the hard rock. Streamflow data support this theory as flows at SGR2 are peakflow dominated with very little baseflow observed. Meanwhile, the coalescing of streamflow and groundwater stable isotope end-members following the significant rains of January 2013, affirm this. As revealed through the ERT data and the low hydraulic gradient from the crest to riparian boreholes, a comparatively flat groundwater level across the profile was identified across the SGR3 hillslope because of the evenness of low resistivity values; meanwhile, the relatively high transmissivity at the midslope to the crest indicates permeable material in shallow (unconsolidated weathered) and deep (fractured hard rock) groundwater flow systems. The gradual two-month response in deeper groundwater levels across all three orders also points towards a regionally connected rather than local groundwater flow system (i.e. larger groundwater catchment area).

In terms of soil hydraulic characteristics, lateral subsurface interflow governs the hillslope processes at the crest towards the stream of SGR3 because of distinct $K_{\text {sat }}$ differences, being high in the A horizon when compared to the underlying horizons. The midslope generally has the lowest $K$ for the entire hillslope, this being attributed to the clay loams. These soils are therefore responsive and have overland flow features because of infiltration excess (shallow responsive), typical during exceptional events. The riparian zone displayed rapid drying cycles, indicative of high evapotranspiration and/or rapid vertical drainage, which is concomitant with the high

TABLE 5: Catena element water budgets ( $\mathrm{mm}$ per annum)

\begin{tabular}{|c|c|c|c|c|c|c|c|c|c|}
\hline & SGR1_C & SGR1_M & SGR1_R & SGR2_C & SGR2_M & SGR2_R & SGR3_C & SGR3_M & SGR3_R \\
\hline$P$ & 637.6 & 637.6 & 637.6 & 637.7 & 637.6 & 637.6 & 637.6 & $640.8 \dagger$ & 637.6 \\
\hline ET & 294.9 & 470.2 & 546.7 & 420 & 507.4 & 354.4 & 457.5 & 496.1 & 382.2 \\
\hline $\mathrm{R}$ & 0 & 0 & 0 & 0 & 0.01 & 22 & 3.2 & 0 & 0 \\
\hline FD & 294.7 & 178.4 & 108.2 & 172.7 & 120.1 & 272.4 & 129.4 & 152.4 & 201.8 \\
\hline$\Delta S$ & 48 & -11 & -17 & 45 & 10 & -11 & 48 & -8 & 54 \\
\hline
\end{tabular}

$C$, crest; $M$, midslope, $R$, riparian zone, $P$, precipitation; $E T$, evapotranspiration; $F D$, free drainage; $S$, change in storage.

$\dagger$, Surface runoff applied from crest position to atmospheric boundary. 
hydraulic conductivity $(K)$ of the soils there. Based on these characteristics, hydrological connectivity between catena elements on this hillslope is highly temporal, being intensity driven with the riparian soils being hydraulically disconnected from the third-order drainage network.

The 1-D modelling provided an indicative water balance at the sub-hillslope level (i.e. by focussing at the scale of the catena unit), stimulating further refinement of the site conceptual model, based on the following narratives: the SGR1 hillslope is dominated by interflows, but most water leaves the soil domain as FD, thereby leading to potential groundwater recharge. This was particularly so during the early rains of October 2012. However, the water balance suggests first-order hillslope connectivity with the adjacent first-order stream through lateral flow (expressed by its low FD); the SGR2 hillslope is also dominated by interflow processes, but as the midslope did not generate overland flow even after high-intensity events, this implies subsurface interflow (at the A/B horizon interface). SGR3 crest comprises interflow soils, midslope with responsive soils, whilst high FD at the riparian zone represents a groundwater recharge zone. Comparing the three hillslopes shows that significant water is removed through ET, particularly so at SGR3. The modelled responses show that there is FD only after high-intensity events. Therefore, a threshold rainfall intensity is required for certain responses such as FD and connectivity between hillslope and stream components. Overall, interflow is the dominant flowpath on these granitic hillslopes.

Although it must be recognised that this study has focussed solely on one small region of the southern granite area of the KNP (Janecke et al. 2020), and in the absence of further hydrological studies in other representative areas, one can only use this to infer an understanding of the hydrological processes in the region more broadly. In summary, therefore, outcomes of the hydrometric observations in the Southern Granite Supersite of the KNP have demonstrated, through observed streamflow, that groundwater hydrodynamics and hydrochemistry are the distinct process zones across the catchment orders. The most striking process being the apparent first-order gains to streamflow arising from hillslope contributions through interflow and a possible perched groundwater wedge, this being because of the strong gradient from shallow groundwater at the crest towards the stream. This contrasts with significant losses observed at the riparian zone of the third-order hillslope. At the scale of the first order, the soils of the valley bottom and foot-slope region cause saturation excess flows (responsive soils), leading to localised hillslope connectivity with the stream at the surface. Overall, midslope responses generally indicate that interflow dominates, this being most apparent at the third order. The variability observed in soil hydrology augments the rationale of Vaughn et al. (2015) that soil texture and resultant hydrology explained variations in woody structure in these sites. This heterogeneity has also been highlighted by Van Tol et al. (2015) as a limitation when developing hydrological models at fine scales using remote methods, notably the omission of wetland responsive soils in the valley bottom at the first order. Similar process responses observed on the first-order granite catchments have been encountered elsewhere in the lowveld region on a similar geological template, albeit under higher rainfall, where perched groundwater contributions to a valley-bottom wetland also led to sustained streamflows at that scale (Riddell et al. 2013). Observations suggested that the third-order stream losses were primarily evapotranspiration driven, with streamflow losses as a result of diffuse flow through the alluvial sediments and thence returned to the atmosphere through the riparian vegetation. Interestingly, the first-order catchment appears to have a greater ET overall as compared to the higher orders, likely explained by accessible vadose zone storage and by augmented flow from the perched seasonal shallow groundwater to the valley bottom. Because of low T-values, the inclining trend of groundwater levels during and following the wet season indicate that the hillslopes act as groundwater storage areas, which in turn sustains a hydraulic head contributing to the regional groundwater flow during the dry season, and thereby providing some baseflow to the perennial rivers of the KNP.

\section{Recommendations for management}

This study has revealed certain important hydro-geological and hydro-ecological interactions relevant also for areas adjacent to the KNP under altered land uses, for instance, the important role that these low-order systems have in catchment processes, notably that streambeds are preferential recharge points. Similar findings of stream channel recharge have been discussed elsewhere in ephemeral river hydroecology (Larned et al. 2010). These ephemeral catchments are critical for regional groundwater recharge processes, and therefore should provide resilience to groundwater management (Kolusu et al. 2019), now threatened because of the growing anthropogenic pressures such as sand extraction in similar drainages outside of the protected area. The low transmissivity of the southern granites and the steady rise in the water level of the weathered and hard rock aquifers could be a geo-hydraulic boundary, characteristic of these ephemeral landscapes. Du Toit and Verster (2017, unpublished) made similar observations at Matlari in the Biyamiti sub-catchment of the Crocodile basin within KNP. It is therefore likely that hydraulic conditions at these watershed areas create a hydraulic gradient through the dry season to lower altitude (high-order) catchments. Implicit in recent studies is that that the perennial rivers of the lowveld at their lower reaches are maintained by regional groundwater contributions (e.g. Gokool et al. 2019; Petersen 2012; SaraivaOkello et al. 2018); this information becomes important for catchment planning purposes through protection of groundwater recharge zones.

The trade-off between recharge and actual evapotranspiration suggests that the groundwater recharge process only follows a threshold 'episodic' rainfall sequence, as noted by Van 
Wyk, Van Tonder and Vermeulen (2011), and in the case of KNP this is typically in the region of $100 \mathrm{~mm} / 24 \mathrm{~h}$. Should rainfall of this intensity not occur, then direct recharge to the aquifer will not take place and the water is otherwise evaporated from the soil matrix. Although general climate forecasts for the region show that the mean annual precipitation will remain the same even though it is likely to arrive in more intense events (e.g. Cuthbert et al. 2019), this in turn could be beneficial as a groundwater recharge mechanism. Meanwhile, this effect may be limited dependent on whether vegetation density increases as a result and the thickness of the vadose zone, as has been shown in the cerrado (Oliveira et al. 2017). This certainly needs to be considered given the significant interannual variability of tree-grass biomass, influenced through wet and dry years, identified as a key determinant of total evaporation at landscape scale from the Skukuza Flux Tower site within the same region of the KNP (Andreu et al. 2019; Williams et al. 2009). Alternatively, an increase in the rainfall intensity could lead to an increase in woody cover and hence aET; this has already been identified as a possible future scenario in other savanna systems (Tietjen 2016).

\section{Conclusion}

This study of the hydrological processes within these ephemeral catchments in the Southern Granite Supersite study has shown that there are interesting mechanisms providing hydrological connectivity at the finer hillslope scale. It has been confirmed that ET dominates the water balance, and that preferential flows connect the hillslopes through interflow processes. Furthermore, the role of ephemeral streambeds in facilitating direct groundwater recharge should not be overlooked, especially when protected areas can provide this function to protect groundwater recharge for the benefit of downstream ecosystems and water users through baseflow provision. This also highlights that protection of riparian zones in ephemeral systems is also critical outside of the protected areas where severe pressures such as sand extraction may have an excessive impact on groundwater-surface water interactions and the vitality of freshwater ecosystems downstream.

\section{Acknowledgements}

The authors thank Dr Izak Smit, Mr Robin Petersen, Mr Annoit Mashele, Mr Difference Thibela, Ms Tercia Strydom and Ms Samantha Mabuza for their contributions to this study. Mr Cobus Pretorius is acknowledged for his technical support and oversight of the stable isotope analysis. Great appreciation is also extended to the DWA Limpopo Drilling Division.

\section{Competing interests}

The authors declare that they have no financial or personal relationships that may have inappropriately influenced them in writing this article.

\section{Authors' contributions}

E.S.R., J.N. and S.L. were involved in the research design and the development of project conceptual framework. E.S.R., D.F., F.J. and A.v.N. were responsible for data collection and analysis. J.v.T. provided interpretation on hydro-pedological contributing processes and manuscript alignment to the themes of the special issue.

\section{Funding information}

The authors are grateful to the Water Research Commission and the Department of Water Affairs for funding this multidisciplinary research.

\section{Data availability}

Data sharing is provided through the SANParks open portal at: http:/ / dataknp.sanparks.org.

\section{Disclaimer}

The views and opinions expressed in this article are those of the authors and do not necessarily reflect the official policy or position of any affiliated agency of the authors.

\section{References}

Abit, S.M., Amoozegar, A., Vepraskas, M.J. \& Niewoehner, C.P., 2008, 'Solute transport in the capillary fringe and shallow groundwater: Field evaluation', Vadose Zone Journal 7(3), 890-898. https://doi.org/10.2136/vzj2007.0102

Andreu, A., Dube, T., Nieto, H., Mudau, A.E., González-Dugo, M.P., Guzinski, R. et al., 2019, 'Remote sensing of water use and water stress in the African savanna ecosystem at local scale-development and validation of a monitoring tool', Physics and Chemistry of the Earth, Parts A/B/C 112, 154-164. https://doi.org/ 10.1016/j.pce.2019.02.004

Ankeny, M.D., Ahmed, M., Kaspar, T.C. \& Horton, R., 1991, 'Simple field method for determining unsaturated hydraulic conductivity', Soil Science of America Journal 55, 467-470. https://doi.org/10.2136/sssaj1991.03615995005500020028x

Bastiaanssen, W.G.M., Menentia, M., Feddes, R.A. \& Holtslag, A.A.M., 1998, 'A remote sensing surface energy balance algorithm for land (SEBAL) 1. Formulation' Journal of Hydrology 212-213, 198-212. https://doi.org/10.1016/S0022-1694 (98)00253-4

Bouwer, H. \& Rice, R.C., 1976, 'A slug test for determining hydraulic conductivity of unconfined aquifers with completely or partially penetrating wells', Water Resources Research 12(3), 423-428. https://doi.org/10.1029/WR012i003p00423

Cooper, H.H. \& Jacob, C.E., 1946, 'A generalized graphical method for evaluating formation constants and summarizing well field history', American Geophysical Union Transactions 27(4), 526-534. https://doi.org/10.1029/TR027i004p00526

Courault, D., Seguin, B. \& Olioso, A., 2005, 'Review on estimation of evapotranspiration from remote sensing data: From empirical to numerical modelling approaches', Irrigation and Drainage Systems 19, 223-249. https://doi.org/10.1007/s10795005-5186-0

Cowan, W.L., 1956, 'Estimating hydraulic roughness coefficients', Agricultural Engineering 37(7), 473-475.

Cullum, C., Brierley, G., Perry, L.W. \& Witkowski, E., 2016, 'Landscape archetypes for ecological classification and mapping: The virtue of vagueness', Progress in Physical Geography 41(1), 95-123. https://doi.org/10.1177/0309133316671103

Cuthbert, M.O., Taylor, R.G., Favreau, G., Todd, M.C., Shamsudduha, M, Villholth, K.G. et al., 2019, 'Observed controls on resilience of groundwater to climate variability in sub-Saharan Africa', Nature 572(7768), 230-234. https://doi.org/10.1038/ s41586-019-1441-7

Dippenaar, M.A. \& Van Rooy, J.L., 2014, 'Review of engineering, hydrogeological and vadose zone hydrological aspects of the Lanseria Gneiss, Goudplaats-Hout River Gneiss and Nelspruit Suite Granite (South Africa)', Journal of African Earth Science 91, 12-31. https://doi.org/10.1016/j.jafrearsci.2013.11.019

Du Toit, W.H., 1998, 'Geohidrologie van die Nasionale Krugerwildtuin gebaseer op die evaluering van bestaande boorgatinligting', vol. 1, Directorate Geohydrology internal report GH 3798, Department of Water Affairs and Forestry, Pretoria.

Du Toit, W.H. \& Verster, H., 2017, 'Establishing a groundwater reference monitoring network in the Kruger National Park: Monitoring the fluctuation of groundwater levels under un-impacted conditions to determine short, medium and long term trends and to estimate tpc levels for abstraction boreholes', report, Department of Water Affairs and Forestry, Pretoria. 
Gokool, S., Riddell, E.S., Nel, J.M., Raubenheimer, R., Strydom, T., Swemmer, A. et al., 2019, 'Quantifying the contribution of riparian total evaporation to streamflow transmission losses: Preliminary investigations along the Groot Letaba river', transmission losses: Preliminary investigations along the Groot Letaba river',
Physics and Chemistry of the Earth, Parts A/B/C 114(1). https://doi.org/10.1016/j. physics and Chem 2019.11 .002

Haga, H., Matsumoto, Y., Matsutani, J., Fujita, M., Nishida, K. \& Sakamoto, Y., 2005 'Flow paths, rainfall properties, and antecedent soil moisture controlling lags to peak discharge in a granitic unchanneled catchment', Water Resources Research 41(12), 1-14. https://doi.org/10.1029/2005WR004236

Hantush, M.S., 1962, Flow of ground water in sands of nonuniform thickness; 3. Flow to wells in Kruseman, G.P. and De Ridder, N.A. (1994). Analysis and evaluation of pumping test data, 2 nd edn., Veenman drukkers, Wageningen.

Herschy, R.W., 1995, Streamflow measurement, 2nd edn., E. \& F.N. Spon, London.

Jacobs, S.M., Bechtold, J.S., Biggs, H.C., Grimm, N.B., Lorentz, S., McClain, M.E. et al., 2007, 'Nutrient vectors and riparian processing: A review with special reference to African Semiarid Savanna Ecosystems', Ecosystems 10(8), 1231-1249. https://doi. org/10.1007/s10021-007-9092-1

Janecke, B.B., 2020, 'Vegetation structure and spatial heterogeneity in the Granite Supersite, Kruger National Park', Koedoe 62(2), a1591. https://doi.org/10.4102/ koedoe.v62i2.1591

Janecke, B.B., Van Tol, J., Smit, I.P.J., Van Aardt, A.C., Riddell, E.S., \& Seaman, M.T. et al., 2020, 'Biotic and abiotic connections on a granitic catena: Framework for multidisciplinary research', Koedoe 62(2), a1600. https://doi.org/10.4102/ koedoe.v62i2.1600

Larned, S.T., Datry, T., Arscott, D.B. \& Tockner, K., 2010, 'Emerging concepts in temporary-river ecology', Freshwater Biology 55(4), 717-738. https://doi.org/ 10.1111/j.1365-2427.2009.02322.x

Loke, M.H., 1999, Electrical imaging survey environment and engineering studies: A practical guide to 2-D and 3D surveys: Geometrics, San Jose, viewed 27 August 2019, from https://pages.mtu.edu/ ctyoung/LOKENOTE.PDF.

Lorentz, S., Bursey K., Idowu, O., Pretorius, C. \& Ngeleka, K., 2008, 'Definition and upscaling of key hydrological processes for application in models', report, Wate Research Commission No 1320/1/08, Gezina, Pretoria.

Kohler, M.A. \& Linsley, R.K., 1951, 'Predicting the runoff from storm rainfall', US Department of Commerce, Government printers, Washington, DC.

Kolusu, R., Shamsudduha, S., Todd, M., Taylor, M.C., Seddon, R.G., Kashaigili, D. et al., 2019, 'The El Niño event of 2015-2016: Climate anomalies and their impact on groundwater resources in East and Southern Africa', Hydrology and Earth System Sciences 23(3), 1751-1762. https://doi.org/10.5194/hess-23-1751-2019

O'Keeffe, J. \& Rogers, K.H., 2003, 'Heterogeneity and management of the Lowveld rivers', in J.T. du Toit, K.H. Rogers \& H.C. Biggs (eds.), The Kruger experience: Ecology and management of savanna heterogeneity, pp. 83-129, Island Press, Washington, DC

Oliveira, P.T.S., Leite, M.B., Mattos, T., Nearing, M.A., Scott, R.L., De Oliveira Xavier, R. et al., 2017, 'Groundwater recharge decrease with increased vegetation density
in the Brazilian cerrado', Ecohydrology 10(1), 1-8. https://doi.org/10.1002/ in the $\mathrm{Brazi}$

Petersen, R.M., 2012, 'A conceptual understanding of groundwater recharge processes and surface-water/groundwater interactions in the Kruger National Park', MSC thesis, Department of Earth Science, University of the Western Cape. http://etd. thesis, Department of Earth Science, Univ
uwc.ac.za/xmlui/handle/11394/5204.

Renshaw, C., HydroToolBox version 1.3, 2010, computer software, Department of Earth Sciences, Hanover, NH.

Richards, L.A., 1931, 'Capillary conduction through porous mediums', Physics 1(5), 318-333. https://doi.org/10.1063/1.1745010

Riddell, E.S., Everson, C., Clulow, A. \& Mengistu, M., 2013, 'The hydrological characterisation and water budget of a South African rehabilitated headwate wetland system', Water SA 39(1), 57-66. https://doi.org/10.4314/wsa.v39i1.8

Rodríguez-Iturbe, I., D'Odorico, P., Porporato, A. \& Ridolfi, L., 1999, 'Tree-grass coexistence in savannas: The role of spatial dynamics and climate fluctuations', Geophysical Research Letters 26(2), 247-250. https://doi.org/10.1029/1998GL 900296

Sankaran, M., Hanan, N.P., Scholes, R.J., Ratnam, J., Augustine, D.J., Cade, B.S. et al., 2005, 'Determinants of woody cover in African savannas', Nature 438(7069), 846-849. https://doi.org/10.1038/nature04070
Saraiva Okello, A.M.L., Uhlenbrook, S., Jewitt, G.P., Masih, I., Riddell, E.S. \& Van der Zaag, P., 2018, 'Hydrograph separation using tracers and digital filters to quantify runoff components in a semi-arid mesoscale catchment', Hydrological Processes 32(10), 1334-1350. https://doi.org/10.1002/hyp.11491

Šimůnek, J., Šejna, M., Saito, H., Sakai M. \& Van Genuchten, MTh., The HYDRUS-1D software package for simulating the movement of water, heat, and multiple solutes in variably saturated media, version 4.17, 2013, computer software, Department of Environmental Sciences, University of California Riverside, Riverside, CA.

Smit, I.P.J., Riddell, E.S., Cullum, C. \& Petersen, R., 2013, 'Kruger National Park research supersites: Establishing long-term research sites for cross-disciplinary, multiscaled learning', Koedoe 55(1), Art. \#1107, 7 pages. https://doi.org/10.4102/koedoe. v55i1.1107

Staver, A.C., 2018, 'Prediction and scale in savanna ecosystems', New Phytologist 219(1), 52-57. https://doi.org/10.1111/nph.14829

Staver, A.C., Botha, J. \& Hedin, L., 2017, 'Soils and fire jointly determine vegetation structure in an African savanna', The New Phytologist 216(4), 1151-1160. https:// doi.org/10.1111/nph.14738

Theis, C.V., 1935, 'The relation between the lowering of the piezometric surface and the rate and duration of discharge of a well using groundwater storage' Transactions of the American Geophysical Union 16(2), 19-524. https://doi.org/ 10.1029/TR016i002p00519

Theron, E., Van Aardt, A.C. \& Du Preez, P.J., 2020, 'Vegetation distribution along a granite catena, southern Kruger National Park', Koedoe 62(2), a1588. https://doi. org/10.4102/koedoe.v62i2.1588

Tietjen, B., 2016, 'Same rainfall amount different vegetation - How environmental conditions and their interactions influence savanna dynamics', Ecological Modelling 326, 13-22. https://doi.org/10.1016/j.ecolmodel.2015.06.013

Uhlenbrook, S., Wenninger, J. \& Lorentz, S.A., 2005, 'What happens after the catchment caught the storm? Hydrological processes at the small, semi-arid Weatherley catchment, South-Africa', Advances in Geoscience 2, 237-241. https://doi.org/10.5194/adgeo-2-237-2005

Van Aardt, A.C., Codron, D., Theron, E. \& Du Preez, P.J., 2020, 'Plant community structure and possible vegetation changes after drought on a granite catena in the Kruger National Park, South Africa', Koedoe 62(2), a1585. https://doi.org/10.4102/ koedoe.v62i2.1585

Van Eekelen, M.W., Bastiaanssen, W.G.M., Jarmain, C., Jackson, B., Ferreira, F., Van der Zaag, P. et al., 2015, 'A novel approach to estimate direct and indirect wate withdrawals from satellite measurements: A case study from the Incomati basin' Agriculture, Ecosystems \& Environment 200, 126-142. https://doi.org/10.1016/j. agee.2014.10.023

Van Tol, J.J., Van Zijl, G.M., Riddell, E.S. \& Fundisi, D., 2015, 'Application of hydropedological insights in hydrological modelling of the Stevenson-Hamilton Research Supersite, Kruger National Park, South Africa', Water SA 41(4), 525-533. https://doi.org/10.4314/wsa.v41i4.12

Van Wyk, E., Van Tonder, G.J. \& Vermeulen, D., 2011, 'Characteristics of local groundwater recharge cycles in South African semi-arid hard rock terrains - Rainwater input', Water SA 37(2), 147-154. https://doi.org/10.4314/wsa.v37i2.65860

Vaughn, N.R., Asner, G.P., Smit, I.P.J. \& Riddel, E.S., 2015, 'Multiple scales of control on the structure and spatial distribution of woody vegetation in African Savanna Watersheds', PLoS One 10(12), 1-17. https://doi.org/10.1371/journal.pone.0145192

Venter, F.J., 1990, 'A classification for land management planning in the Kruger National Park', PhD thesis, University of South Africa, Pretoria.

Venter, F.J., Scholes, R.J. \& Eckhardt, H.C., 2003, 'The abiotic template and its associated vegetation pattern', in J.T. du Toit, K.H. Rogers \& H.C. Biggs (eds.), The Kruger experience: Ecology and management of savanna heterogeneity, pp. 83-129, Island Press, Washington, DC.

Walter, H., 1971, Ecology of tropical and subtropical vegetation, Oliver and Boyd, Edinburgh.

Wenninger, J., Uhlenbrook, S., Lorentz, S. \& Leibundgut, C., 2008, 'Identification of runoff generation processes using combined hydrometric, tracer and geophysical methods in a headwater catchment in South Africa', Hydrological Sciences Journa 53(1), 65-80. https://doi.org/10.1623/hysj.53.1.65

Williams, C.A., Hanan, N., Scholes, R.J. \& Kutsch, W., 2009, 'Complexity in water and carbon dioxide fluxes following rain pulses in an African savanna', Oecologia 161(3), 469-480. https://doi.org/10.1007/s00442-009-1405-y 